\title{
PENGARUH KEPEMIMPINAN DAN KOMPETENSI TERHADAP KINERJA GURU SMK ATLANTIK
}

\author{
Ardhi Ashadi', Widodo ${ }^{2}$ \\ STKIP Kumala Metro \\ ardhiashadi@kumala.ac.id ${ }^{1}$, widodomurnasih@gmail.com²
}

\begin{abstract}
ABSTRAK
Penelitian ini bertujuan untuk mengetahui pengaruh kepemimpinan dan kompetensi terhadap kinerja guru di SMK Atlantik. Kepemimpinan (X1) dan kompetensi (X2) adalah variabel bebas, kinerja guru (Y) adalah variabel terikat. Berdasarkan hasil penelitian, maka diperoleh kesimpulan sebagai berikut: (1) Ditemukan hubungan yang positif dan signifikan antara kepemimpinan (variabel X1) terhadap kinerja guru (variabel Y) dengan hasil korelasi diperoleh angka 70,8\%, jadi ho ditolak dan ha diterima (2) Ditemukan yang koneksi positif dan signifikan karena mendapat angka $81,4 \%$, jadi ho ditolak dan ha diterima antara kompetensi (X2) terhadap kinerja guru (Y). (3) Karena mendapatkan hasil 83,3\% berarti secara bersama-sama ditemukan yang merupakan hubungan positif dan signifikan antara variabel kepemimpinan kepala sekolah (X1) dan variabel motivasi (X2) terhadap variabel kinerja guru (Y).
\end{abstract}

Kata kunci: Kepemimpinan, Kompetensi, Kinerja

\begin{abstract}
This study is aims to examine to the effects of leadership and competence toward the teacher's performance in SMK Atlantik. Leadership (X1) and competence (X2) are independent variables and the performance of the teacher $(\mathrm{Y})$ is dependent variable. Based on the results of the study, then obtained the following conclusions: (1) found a positive and significant relationship between leadership (variable X1) to the performance of the teacher (variable Y) with the correlation result obtained a number of $70.8 \%$, so Ho rejected and Ha accepted (2) found that the connection is positive and significant because it gets a figure of $81.4 \%$, so Ho rejected and Ha accepted between competence (X2) on teacher performance (Y). (3) Since getting $83.3 \%$ results means collectively found which is a positive and significant relationship between the principal's leadership variables (X1) and the motivational variables (X2) against the teacher's performance variable (Y).
\end{abstract}

Keywords: Leadership, Competence, Performance

\section{PENDAHULUAN}

Dalam rangka meningkatnya kemampuan teknologi bahasa adalah upaya besar dan dalam pelaksanaannya penyampaian bahasa yang baik merupakan upaya bersama dan saling mengisi antar pemerintah dan masyarakat. Melalui program pendidikan, pengembangan ilmu pengetahuan teknologi serta program penelitian, pemerintah terus mendorong peningkatan kemampuan teknologi. Sementara itu dunia usaha harus memainkan peranan aktif dalam mengembangkan, menjembatani dan memanfaatkannya dalam kegiatan nyata (Presiden Soeharto, Pidato Kenegaraan Di depan sidang DPR 15 Agustus 1992).

Bahwa pendidikan dapat meningkatkan kualitas sumber daya manusia tentunya akan terbantu pada 
banyak hal seperti pendidik. Jika semuanya dalam kualitas prima tentu saja hasilnya juga akan prima, sehingga diperoleh sumber daya manusia yang berkualitas.

Ilmu dan teknologi yang berkembang dengan cepat perlu diimbangi dengan perubahan kemampuan dan keterampilan, sebab pesatnya ilmu menentukan kemampuan tersendiri. Dalam kaitan itu pesatnya ilmu menentukan kemampuan tersendiri. Dalam kaitannya itu pembangunan ketenagakerjaan yang dilakukan melalui pengembangan Sumber Daya Manusia harus saling terkait dan terpadu dengan Sistem Pendidikan Nasional, pelatihan kerja dan program pembangunan.

Salah satu masalah yang dihadapi dunia pendidikan nasional dewasa ini adalah kualitas kepemimpinan yang jauh tercecer dari keberhasilan pencapaian target kualitas. Hal ini bukannya tidak disadari dalam perencanaan pembangunan nasional kita. Secara sadar perencanaan sektor pendidikan selama ini diarahkan pada azas pemerataan untuk memberikan kesempataan yang seluas - luasnya bagi semua warga Negara untuk memperoleh pendidikan dan secara bertahap peningkatan kualitas pendidikan. Dengan hanya meningkatkan kualitas pendidikan saja agaknya terlalu mahal bagi pembangunan suatu masyarakat yang cerdas dan berwawasan kesatuan bangsa.

Untuk memperoleh mutu pendidikan yang baik dan diharapkan era yang terjadi sekarang ini, maka SMK Atlantik harus didukung oleh suatu sistem manejemen yang baik pula, disamping didukung oleh sarana dan prasarana yang memadai.

Salah satu faktor yang dibutuhkan dalam menciptakan sistem manajemen yang baik adalah faktor kepemimpinan. Di lembaga pendidikan atau sekolah dibutuhkan pula pola kepemimpinan yang handal dan fungsi manajemen sekolah yang menjadi tangung jawabnya, sehingga diharapkan dapat terus mampu meningkatkan mutu pendidikan maupun mutu guru.

Dalam suatu lembaga atau organisasi, peranan pemimpin sangat sentral, karena pemimpin merupakan pusat posisi dalam kelompok, organisasi atau lembaga memainkan peranan penting dalam pelaksanaan program untuk mencapai tujuan lembaga, ideologi kelompok, struktur kelompok dan didalam pencapaian aktivitas - aktivitas yang disetujui dalam lembaga tersebut.

Hierarki kepemimpinan berkembang dalam suatu organisasi yang tumbuh menjadi besar dan kompleks karena tuntutan dan fungsi pemimpin organisasi serta pelengkap tujuan organisasi meningkat.

Keahlian seorang pemimpin didalam melaksanakan tugas sangat diperlukan, karena seorang pemimpin harus terlihat mempunyai media yang paling baik dilakukan dalam memimpin pegawai. Seorang pemimpin harus berkonsentrasi terhadap tugas - tugas lembaga memainkan peranan yang agresif didalam menggerakkan lembaga untuk untuk mencapai program yang di rencanakan.

Didalam organisasi, kemampuan dengan memiliki motivasi untuk berprestasi guna meningkatkan kinerja merupakan prestasi guru dan karyawan. Berarti organisasi tersebut berjalan sesuai harapan lembaga yaitu memiliki tingkat yang tinggi, semangat kerja guru dan jaryawan sangat pula dipengaruhi suasana kerja yang menyenangkan.

\section{A. Kepemimpinan}

Kepemimpinan adalah suatu kegiatan dalam memfasilitasi kelompok untuk mencapai tujuan bersama. Dalam memfasilitasi kelompok, seorang pemimpin mempunyai misi untuk mempengaruhi, mendorong, mengajak, menuntun, menggerakkan dan jika perlu memaksa 
orang lain atau kelompok agar mereka melakukan sesuatu yang terkait dengan pencapaian tujuan bersama.

Berdasarkan konsepsi tersebut, pengertian kepemimpinan dalam hal ini mempunyai unsur-unsur, sebagai berikut: a) Orang yang dapat mempengaruhi, b) Terdapat orang yang dapat pengaruh di lain pihak, c) Adanya maksud atau tujuan tertentu yang hendak dicapai bersama, d) Adanya serangkaian tindakan tertentu untuk mempengaruhi dan untuk mencapai suatu tujuan.

Ahli lain mendefinisikan kepemimpinan sebagai keseluruhan tindakan guna mempengaruhi dan menggerakkan orang lain tersebut bekerja sesuai dengan keinginan. Carter dan Dubin menjelaskan bahwa konsep menjelaskan bahwa konsep kepemimpinan dan kekuasaan sebagai satu kesatuan yang saling melengkapi. Kekuasaan merupakan sarana bagi pemimpin untuk mempengaruhi perilaku. Pengikut-pengikutnya, agar para pengikut tersebut bekerja secara optimal untuk mewujudkan suatu tujuan organisasi.

Beberapa definisi yang disampaikan oleh para pakar di bidang kepemimpinan adalah sebagai berikut:

1. George R. Tery menyebutkan bahwa kepemimpinan adalah keseluruhan kegiatan (aktivitas) untuk mempengaruhi kemauan orang lain untuk mencapai tujuan bersama (Leadership is activity of influencing people to strive willingly for mutual objectives).

2. Robert Dubin memyebutkan bahwa kepemimpinan adalah aktivitas pemegang kewenangan dan pengambil keputusan (Leadership is the exercise of authority and making of decisions).

3. Sondang.P. Siagian menyebutkan bahwa kepemimpinan merupakan inti dari manajemen, karena kepemimpinan adalah motor penggerak bagi Sumber Daya Manusia dan Sumber Daya Alam lainnya.

Dari uraian di atas, untuk mendapatkan kepemimpinan yang ideal, makakonsep tersebut di atas harus dipadukan karena ketiga konsep tersebut saling melengkapi. Berdasarkan beberapa pendapat di atas, dapat disimpulkan bahwa kepemimpinan adalah keseluruhan tindakan seseorang (kepala sekolah) untuk mempengaruhi bawahannya yang didasari atas sifat yang dimiliki, sehingga orang lain mau bekerja secara optimal dalam mewujudkan tujuan organisasi.

\section{B. Kompetensi}

Dalam rangka meningkatkan profesionalisasi yang akan rnenjamin peningkatan mutu kinerja sejalan dengan arus informasi dibidang pendidikan dan semangat otonomi pendidikan perlu adanya usaha yang urgen terhadap tinjauan kembali profesi kinerja yang berkaitan dengan kompetensi tugas, dan fungsi serta sikap dan etos kerja salah satu komponen yang diharapkan dapat meningkatkan profesionalisme kinerja adalah melalui pendidikan dan pelatihan.

Guru yang profesional diharapkan dapat melaksanakan tugas dan fungsinya sedemikian rupa yang tidak semua orang (awam) dapat melakukannya, artinya tugas dan fungsi guru hanya khusus dilakukan oleh orang yang berwenang menjadi guru.

Kompetensi diartikan sebagai proses yang dinamis, terbuka, kontektual dan merupakan suatu 
keadaan "menjadi ("a state of becoming") profes kompetensi sangat dimotivasi oleh guru itu sendiri.

Kompetensi perlu dilihat dalam kaitannya dengan pembangan paradigma baru di era reformasi dan otonimisasi bidang pendidikan. Pengembangan kompetensi sebagai tujuan kinerja dapat terjaciidalam berbagai tingkatan. Penguasaan kompetensi yang hanya sekedar mampu berpartisipasi untuk memutar roda suatu system tanpa memahami secara luas kemana arah dari pelerakan system itu disebut sebagai orang yang capable atau sering disebut sebagai "tukang". Guru berkemampuan seperti itu belum mempunyai wawasan yang luas tentang apa yang akan dikerjakan karenanya tidak mampu berinovasi dalam bekerja. Ia turut dalam system tetapi ia tidak tahu kemana arah system itu.. Penguasafrn kompetensi pada tahap yang lebih tinggi mengakibatkan seseorang tidak saja hanya berpartisipasi dalam memutar roda sistem, tetapi ia juga mengetahui dan menyadari arah dari sistem itu. Walaupun ia tidak mampu menciptakan atau mengubah sistem tetapi ia mempunyai komitmen terhadap sistem yang ada, ia dapat disebut sebagai tenaga yang semi profesional.

Kemampuan dan keterampilan mendapatkan perhatian yang cukup besar dalam lingkungan manajemen masa kini. Penggunaan istilah kompetensi merupakan istilah yang digunakan untuk menjelaskan pengertian kemampuan. Robert
Kreitner dalam Angelo Kinicki (2003: h. 185) mengatakan:

"Kemampuan (Kompetensi) menunjukan ciri khas dan karakteristik tanggung jawab yang stabil pada tingkat prestasi yairg maksimal berlawanan dengan kemampuan kerja mental maupun fisik. Keterampilan (kompetensi) disisi lain adalah kapasitas khusus untuk memanipulasi objek secara fisik".

Selanjutnya menurut Robert Kreitner dalam Angelo Kinicki (2003 : h. 185) rrrengatakan: "Tentang kompetensi diidentifikasikan pengelompokan kelompok pengetahuan, sikap dan keterampilan yang dibutuh (Syamsudin, 1997) (Syamsudin, Psikologi Pendidikan, 2003)kan untuk melakukan bagian pekerjaan. Kompetensi rnenjadi dasar untuk menentukan rekrutan, pelatihan, promosi yang berkaitan dengan Sumber Daya Manusia".

Dari uraian diatas dapat diambil suatu kesimpulan bahwa kompetensi berkaitan dengan spesifikasi pekerjaan (Job Specification) disusun berdasakan uraian pekerjaan dengan menjawab pertanyaan tentang ciri, karakteristik, pendidikan, pengalaman dan 1'ang lairurya dari orang yang akan melaksanakan pekerjaan tersebut dengan baik.

\section{Kinerja}

Guru Pendidik dan Pengajar, Tugas dan tanggung jawab guru sebagai pendidik (educator) dengan 
pengajar (teacher) dalam arti yang lebih luas konsep mendidik mencakup seluruh proses hidup dan segenap bentuk interaksi individu dengan lingkungannya baik secara formal maupun non formal dalam kontek ini kinerja guru. Untuk mewujudkan dirinya sesuai dengan tahapan tugas yang harus dikerjakan dalam tahapan pelaksanaan tugas secara optimal. Menurut Abin Syamsudin (1997: h. 18) mengatakan bahwa seorang guru bertugas dan bekerja berperan sebagai:

(a) Konservator (pemelihara) system nilai yang merupakan sumber norma kedewasaan dan inovator (pengembang) system ilmu pengetahuan. (b) Transmitor (penerus) sistem-sistem nilai tersebut kepada peserta didik. (c) Transformator (penerjemah) sistem-sistem nilai melalui penjelmaan dalam pribadi dan perilakunya melalui proses interaksinya dengan peserta didik. (d) Organisator (penyelenggara) terciptanya proses edukatif yang dapat dipertanggung jawabkan baik secara formal (kepada pihak yang mengangkat dan menugaskannya) maupun secara moral (kepada peserta didik serta Tuhan yang menciptakannya).

Menurut pendapat tersebut di atas kinerja Guru tidaklah sebatas bertugas dan berperan, namun dikenal juga sebagai pengajar yang mengajar dalam suatu proses interaksi belajar dan mengajar dalam bentuk formal, maka seorang guru terikat juga dengan pertanggungjawaban.

Menurut pendapat Gagne and Berliner dalam Abin Syamsudin (1997: h. 19) mengatakan bahwa bertugas dan petanggungan jawab guru adalah sebagai berikut: (a) Perencana (Planner) yang harus mempersiapkan apa yang akan dilakukan di dalam proses pembelajaran (Preteaching Problem). (b) Pelaksana (Organizer) yang harus menciptakan situasi, memimpin, merangsang, menggerakkan dan mengarahkan kegiatan pembelajaran sesuai dengan rencana ia bertindak sebagai narasumber, sebagai leader yang bijaksana dalam arti demokrastis dan manusiawi humanities (humanities) selama proses pembelajaran berlangsung. (c) Penilai (Evaluator) yang harus mengumpulkan, menganalisa, menafsirkan dan akhirnya harus memberikan pertimbangan (Judgemen) atas tingkat keberhasilan pembelajaran tersebut berdasarkan kriteria yang ditetapkan.

Kinerja guru dapat didefenisikan sebagai kemampuan guru dalam melaksanakan keseluruhan proses kerja sejak penyusunan rencana, pelaksanaan dan hingga hasil kerjanya. Dan selanjutnya menurut Rusli Syarif (1991: h.103) mengatakan bahwa:

"Produktivitas/prestasi individu tergantung kepada kesediaan atau kemauan kerjanya dan keterampilan kerjanya. Kesediaan kemauan kerja sangat dipengaruhi oleh situasi dan kondisi kerja yang dihadapinya dan sikapnya terhadap pekerjaannya dan kondisi kerjanya itu. Keterampilan kerja sangat tergantung dari kemampuan pribadinya serta pengalaman dan latihan kerja yang 
dialaminya. Sedangkan

kemampuan pribadinya sangat

dipengaruhi oleh bakat yang

dibawanya sejak lahir dan

pengetahuan yang diperolehnya dari pendidikan formal maupun nonformal yang ditempuhnya".

\section{Kerangka Pemikiran}

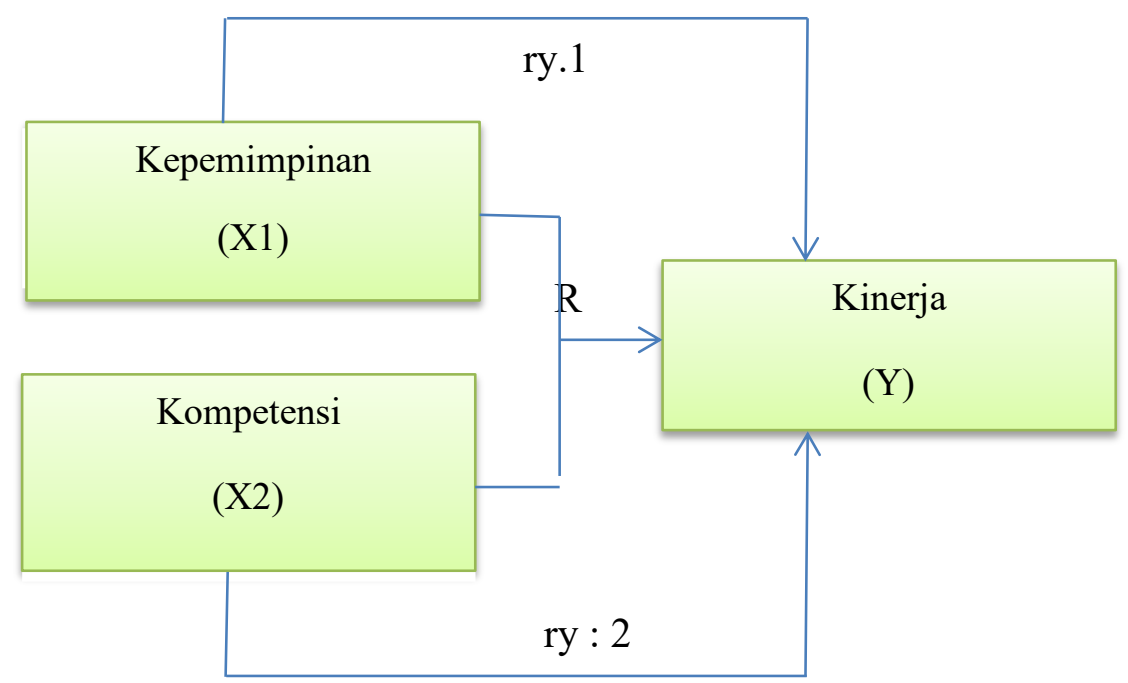

Gambar 1. Kerangka Pemikiran

Keterangan:

$\mathrm{X} 1=$ variabel bebas kepemimpinan

$\mathrm{X} 2=$ variabel bebas kompetensi

$\mathrm{Y} \quad=$ variabel terikat kinerja

ry1 = Pengaruh secara parsial antara

variabel kepemimpinan terhadap kinerja

ry2 = Pengaruh secara parsial antara variabel kompetensi terhadap kinerja

$\mathrm{R} \quad=$ Pengaruh secara simultanl antara variabel kepemimpinan dan kompetensi terhadap kinerja.

\section{E. Hipotesis}

Berdasarkan deskripsi teori dan kerangka berpikir yang telah diuraikan dimuka, maka dikemukakan hipotesis yang dilakukan adalah sebagai berikut:

1. Terdapat pengaruh yang signifikan dan positif antara kepeminpinan (X1) terhadap kinerja guru (Y).

2. Terdapat pengaruh yang signifikan dan positif antara kompetensi (X2) terhadap kinerja guru.
3. Terdapat pengaruh yang signifikan dan positif antara kepemimpinan (X1) dan kompetensi (X2) terhadap kinerja guru (Y).

\section{METODE PENELITIAN}

Penelitian ini dilakukan SMK Atlantik pada bulan Januari 2019 sampai dengan bulan April 2019. Penelitian ini menggunakan metode deskriptif kuantitatif untuk menjelaskan pengaruh variabel independen X1 dan X2 terhadap variabel dependen $\mathrm{Y}$.

\section{A. Populasi dan Sampel}

Populasi dalam penelitian ini adalah 50 guru pada SMK Atlantik, dengan teknik total sampel atau sensus.

\section{B. Definisi Operasional Variabel}

1. Variabel kepemimpinan (XI) adalah penilaian pegawai terhadap kemampuan pimpinan yakni kepala sekolah dalam menjalankan fungsi 
dan peranannya sebagai kepala SMK Atlantik. Dari variabel ini terdapat aspek-aspek: bidang tugas kepekaan terhadap lingkungan, kemampuan menjalankan hubungan kerja antar manusia kemampuan melakukan koordinasi, proses pengambilan keputusan dan interaksi dengan masyarakat.

2. Variabel kompetensi (X2) adalah segala aktivitas yang dilakukan oleh pegawai dalam menjalankan tugasnya secara terprogram dan terencana. Dari variabel ini terdapat aspek: keterampilan, tanggung jawab, kecenderungan meningkatkan pekerjaan, kemampuan bidang pekerjaan, dan aspek kemampuan pribadi.

3. Variabel kinerja guru dan karyawan (Y) adalah kemampuan pegawai dalam melaksanakan tugas, hasil yang dicapai, upaya peningkatan mutu, pengembangan diri dan aspek penilaian atau evaluasi terhadap pegawai.

Dari setiap penelitian tersebut dibuatkan angket yang disebarkan kepada responden untuk dimintai tanggapannya yang berkaitan dengan penelitian, yakni sebagai berikut:

1. Variabel penelitian merupakan instrumen penelitian

Kepemimpinan (X1) jumlah soal 10
Kompetensi (X2) jumlah soal 10

$>$ Kinerja Pegawai (Y) jumlah soal 10

2. Skor instrumen penelitian

$>$ Alternatif jawaban A dengan skor nilai 5

Alternatif jawaban B dengan skor nilai 4

Alternatif jawaban $\mathrm{C}$ dengan skor nilai 3

Alternatif jawaban D dengan skor nilai 2

Alternatif jawaban E dengan skor nilai 1

\section{HASIL DAN PEMBAHASAN}

Hasil penelitian untuk variabel X1 menyebutkan $38,07 \%$ menjawab $\mathrm{A}$. sebesar 31,43\% menjawab B, sebanyak 29,38\% menjawab C, dan menjawab D sebanyak $1,12 \%$. Hasil penelitian untuk variabel X2 menyebutkan 39,47\% menjawab A. 30,69\% menjawab B. Selanjutnya, terdapat $25,81 \%$ responden yang memilih alternatif jawaban $\mathrm{C}$, dan yang menjawab D sebanyak $4,03 \%$. Hasil penelitian untuk variabel $\mathrm{Y}$ hanya $36,83 \%$ menjawab A. Kemudian 33,51\% responden yang memilih alternatif jawaban B. Selanjutnya, terdapat 26,30 $\%$ responden yang memilih alternatif jawaban C, dan Responden yang menjawab D sebanyak 3,39\%.

\section{A. Pengaruh antara Kepemimpinan} $\left(\mathrm{X}_{1}\right)$ terhadap Kinerja (Y)

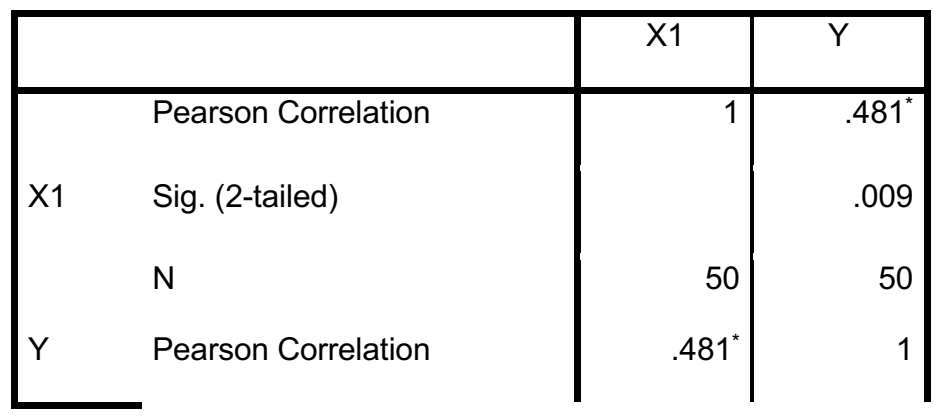


(ISSN Cetak 1978-6573) (ISSN Online 2477-300X)

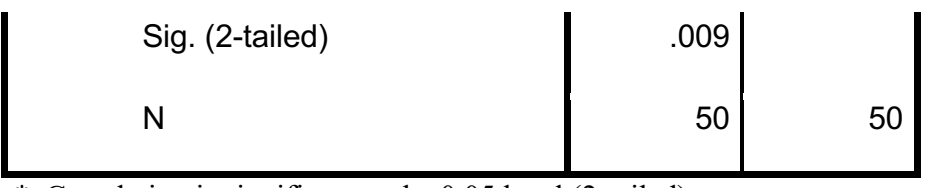

*. Correlation is significant at the 0.05 level (2-tailed).

Sumber: Diolah Peneliti (2019)

\section{B. Pengaruh Kompetensi $\left(\mathrm{X}_{2}\right)$ terhadap Kinerja (Y)}

Tabel 1. Korelasi X2 terhadap Y

\begin{tabular}{|c|c|c|c|}
\hline & & $\mathrm{X} 2$ & $\mathrm{Y}$ \\
\hline \multirow{3}{*}{$\mathrm{X} 2$} & Pearson Correlation & 1 & $.453^{*}$ \\
\hline & Sig. (2-tailed) & & .002 \\
\hline & $\mathrm{N}$ & 50 & 50 \\
\hline \multirow{3}{*}{$\mathrm{Y}$} & Pearson Correlation & $.453^{*}$ & 1 \\
\hline & Sig. (2-tailed) & .002 & \\
\hline & $\mathrm{N}$ & 50 & 50 \\
\hline
\end{tabular}

Sumber: Diolah Peneliti (2019)

Untuk uji signifikasinya:

Ho: Tidak ada pengaruh secara parsial antara Kepemimpinan $\left(\mathrm{X}_{1}\right)$ dan Kompetensi $\left(\mathrm{X}_{2}\right)$ terhadap Kinerja $(\mathrm{Y})$

Ha: Ada pengaruh secara parsial antara Kepemimpinan $\left(\mathrm{X}_{1}\right)$ dan Kompetensi $\left(\mathrm{X}_{2}\right)$ terhadap Kinerja (Y)

Dasar pengambilan keputusan: jika angka korelasi lebih kecil dari 0,01 maka Ho ditolak artinya ada hubungan dan jika angka korelasi lebih besar dari 0,01 maka ho diterima artinya tidak ada pengaruh.

Dari pengolahan data tingkat signifikasi diperoleh angka 0,009 (Tabel 1) untuk pengaruh Kepemimpinan $\left(\mathrm{X}_{1}\right)$ terhadap Kinerja (Y) diperoleh angka 48,1\%, maka Ho ditolak dan Ha diterima artinya terdapat pengaruh yang siginifikan, selanjutnya $51,9 \%$ lagi dipengaruhi oleh variabel lain yang tidak diteliti. Dari pengolahan data tingkat signifikasi diperoleh angka 0,002 (Tabel 2) untuk pengaruh kompetensi $\left(\mathrm{X}_{2}\right)$ terhadap kinerja (Y) diperoleh angka 45,3\%, maka Ho ditolak dan Ha diterima artinya terdapat pengaruh yang siginifikan, selanjutnya $54,7 \%$ lagi dipengaruhi oleh variabel lain yang tidak diteliti. Untuk mengetahui apakah terdapat pengaruh yang signifikan secara bersama-sama antara Kepemimpinan (X1) dan Kompetensi (X2) terhadap Kinerja (Y), berikut disajikan tabel perbandingan atau harga kritik dari Spearmen:

Tabel 3. Harga Kritik dari Spearmen

\begin{tabular}{|c|c|c|c|c|c|}
\hline \multirow[b]{2}{*}{$\mathrm{N}$} & Tar & Sinif & \multirow[b]{2}{*}{$\mathrm{N}$} & Taraf & Sinif \\
\hline & $5 \%$ & $1 \%$ & & $5 \%$ & $1 \%$ \\
\hline 5 & 1,000 & - & 16 & 0,506 & 0,665 \\
\hline
\end{tabular}


(ISSN Cetak 1978-6573) (ISSN Online 2477-300X)

\begin{tabular}{|c|c|c|c|c|c|}
\hline 6 & 0,886 & 0,992 & 18 & 0,475 & 0,625 \\
7 & 0,786 & 0,929 & 20 & 0,450 & 0,591 \\
8 & 0,738 & 0,881 & 22 & 0,428 & 0,562 \\
9 & 0,683 & 0,833 & 24 & 0,409 & 0,526 \\
10 & 0,648 & 0,794 & 26 & 0,392 & 0,515 \\
12 & 0,591 & 0,777 & 28 & 0,377 & 0,496 \\
14 & 0,544 & 0,715 & 30 & 0,364 & 0,478 \\
\hline
\end{tabular}

Sumber: Sugiyono (2017)

Dibawah ini ditunjukkan oleh Tabel 4 dari hasil analisis secara bersamasama (simultan) yang telah diproses melalui program Statistical Product and Service Solutions (SPSS), hal tersebut dilakukan untuk proses lebih lanjut.

Tabel 4. Model Summary

\begin{tabular}{|l|r|r|r|r|}
\hline Model & \multicolumn{1}{|c|}{$\mathrm{R}$} & R Square & \multicolumn{1}{c|}{$\begin{array}{c}\text { Adjusted R } \\
\text { Square }\end{array}$} & \multicolumn{1}{c|}{$\begin{array}{c}\text { Std. Error of the } \\
\text { Estimate }\end{array}$} \\
\hline 1 & $.644^{\mathrm{a}}$ & .679 & .667 & 2.17757 \\
\hline
\end{tabular}

a. Predictors: (Constant), X2, X1

Sumber: Diolah Peneliti (2019)

Berdasarkan hasil pengolahan data melalui program Statistical Product and Service Solutions (SPSS) dari N $=50$ memperoleh hasil 0,644 atau $64,4 \%$ (tabel : 4) yang ternyata lebih besar dari Harga Kritik dari Spearmen (Tabel 3), $\mathrm{N}=30$ dengan tingkat kepercayaan 95\% yaitu 0,364 berarti secara bersama-sama terdapat pengaruh yang signifikan antara Kepemimpinan (X1) dan Kompetensi (X2) terhadap Kinerja (Y) sedangkan 35,6\% dipengaruhi oleh variabel lain yang tidak diteliti.

Berdasarkan data yang ada dengan pengolahan SPSS, Santoso menyatakan tentang tingkat korelasi antar variabel, bahwa angka berkisar 0 (tidak ada korelasi sama sekali) dan 1 (korelasi sangat sempurna) berarti angka korelasi 0,5 menunjukkan korelasi yang cukup kuat, sedangkan dibawah 0,5 korelasi lemah. Pada hasil analisis data diatas adalah:

1. Kepemimpinan (X1) dan Kinerja (Y) diperoleh pengaruh $+0,481$ atau $48,1 \%$, hal ini menunjukan lebih kecil dari 0,5 ini berarti pengaruhnya masih rendah. Sedangkan tanda positif $(+)$ menunjukan bahwa semakin tinggi kepemimpinan, maka akan semakin tinggi Kinerja. Berarti 51,9\% dipengaruhi oleh variable lain yang tidak diteliti. Untuk memperjelas hubungan kedua variabel tersebut bisa dilihat dengan gambar (kurva) sebagai berikut: 


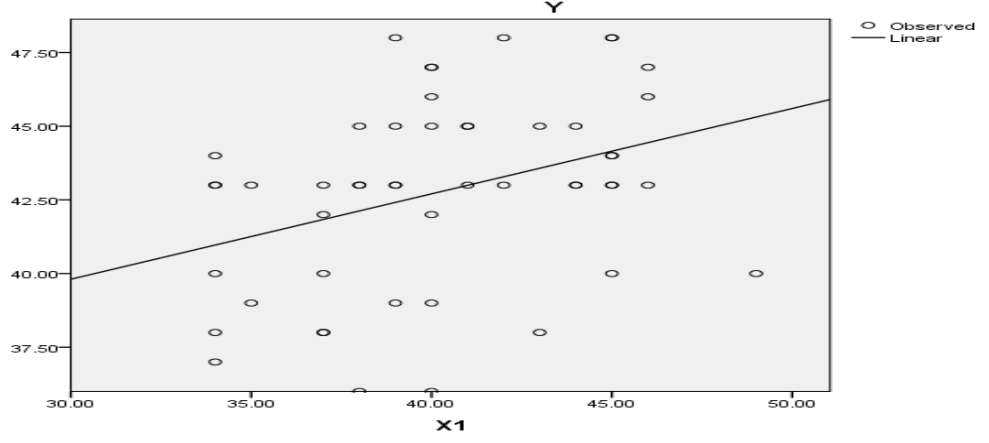

Sumber: Diolah Peneliti (2019)

\section{Gambar 2. Curve Fit}

2. Kompetensi $\left(\mathrm{X}_{2}\right)$ dan Kinerja (Y) diperoleh koefisien korelasi $+0,453$ atau $45,3 \%$, hal ini menunjukan lebih kecil dari 0,5 ini pengaruhnya sedang. Sedangkan tanda positif $(+)$ menunjukan bahwa semakin tinggi Pelayanan, maka akan semakin tinggi
Kepuasan Pelanggan dan berarti 54,7\% lagi dipengaruhi oleh variabel lain yang tidak diteliti. Untuk memperjelas hubungan kedua variabel tersebut bisa dilihat dengan gambar (kurva) sebagai berikut:

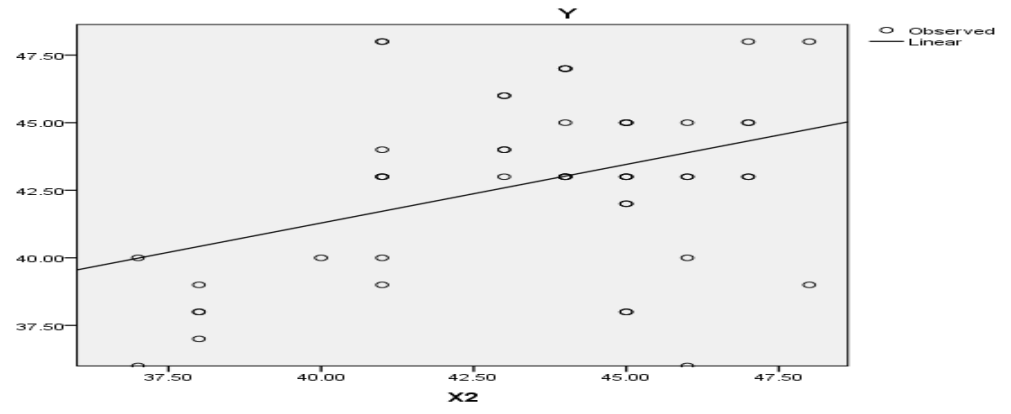

Sumber: Diolah Peneliti (2019)

Gambar 3. Curve Fit

3. Untuk melihat pengaruh secara bersama-sama (simultan) adalah sebagai berikut: Kepemimpinan (X1) dan kompetensi (X2) secara bersamasama terhadap Kinerja (Y) sebesar + 0,644 atau $64,4 \%$ hal ini menunjukan lebih besar dari 0,5 ini berarti mempunyai pengaruh yang kuat. Sedangkan tanda positif (+)

\section{KESIMPULAN DAN SARAN}

\section{A. Kesimpulan}

1. Pengaruh kepemimpinan $\left(\mathrm{X}_{1}\right)$ terhadap Kinerja (Y), diperoleh angka 0,009 maka Ho ditolak dan menunjukan bahwa semakin tinggi kepemimpinan dan Kompetensi, maka akan semakin tinggi Kinerja dan sebaliknya semakin rendah kepemimpinan dan Kometensi, maka akan semakin rendah pula Kinerja dan $35,6 \%$ lagi dipengaruhi oleh variabel lain yang tidak diteliti.

Ha diterima artinya terdapat pengaruh yang siginifikan.

2. Pengaruh Kompetensi $\left(\mathrm{X}_{2}\right)$ terhadap Kinerja (Y) diperoleh angka 0,002, maka Ho ditolak 
dan Ha diterima artinya terdapat pengaruh yang siginifikan.

3. Berdasarkan hasil pengolahan data melalui program Statistical Product and Service Solutions (SPSS) dari $\mathrm{N}=50$ memperoleh hasil 0,644 lebih besar dari Harga Kritik dari Spearmen N=30 dengan tingkat kepercayaan 95\% yaitu 0,364 berarti secara bersama-sama terdapat pengaruh yang signifikan antara kepemimpinan (X1) dan Kompetensi (X2) terhadap Kinerja (Y).

B. Saran

1. Kepemimpinan harus ditingkatkan melalui sikap yang harmonis dan fariatif serta sesuai dengan keinginan atau kehendak bawahan, lingkungan dan kenyamanan harus diperhatikan agar tetap dapat dinikmati oleh para bawahan, karena baru $38,07 \%$ menyatakan sangat baik. $30,43 \%$ menyatakan baik. 29,38 $\%$ menyatakan cukup dan $2,12 \%$ menyatakan tidak baik.

2. Baru 39,47\% responden menyatakan Kompetensi sangat baik. $\quad 30,69 \% \quad$ responden menyatakan baik. 25,81\% responden menyatakan cukup, 4,03\% menyatakan tidak baik, maka perlu peningkatan kualitas dan kompetensi.

3. Kinerja perlu ditingkatkan karena terlihat bahwa $36,83 \%$ menyatakan sangat baik, 33,51\% responden menyatakan baik. $26,30 \%$ responden menyatakan cukup, $\quad 3,39 \% \quad$ responden menyatakan tidak.

\section{DAFTAR PUSTAKA}

Dubin, C.D. (1992). Manajemen Kepemimpinan. Jakarta: Bumi Aksara.

Kinicki, A. (2003). Kepemimpinan Enterpreuner di Pendidikan Kejuruan. Jakarta: Salemba Empat. Syamsudin, A. (1997). Psikologi Kependidikan. Bandung: Remaja Rosdakarya.

Syamsudin, A. (2003). Psikologi Pendidikan. Bandung: Remaja Rosdakarya.

Syarif, R. (1991). Produktivitas. Bandung: Angkasa. 